\title{
Early deposition of n-3 fatty acids from tuna oil in lean and adipose tissue of fattening pigs is mainly permanent ${ }^{1}$
}

\author{
S. Jaturasitha, ${ }^{* 2}$ R. Khiaosa-ard, ${ }^{*} \dagger$ P. Pongpiachan, ${ }^{*}$ and M. Kreuzer $\dagger$ \\ *Department of Animal Science, Faculty of Agriculture, Chiang Mai University, Chiang Mai 50200, Thailand; \\ and †ETH Zurich, Department of Agricultural and Food Science, \\ Universitaetstrasse 2, CH-8092 Zurich, Switzerland
}

\begin{abstract}
A total of 600 crossbred pigs, whereof 56 were randomly selected for more in-depth studies of carcass and pork quality, were employed to test different tuna oil feeding regimens. The focus was put on the efficiency to enrich lean and adipose tissue with n-3 fatty acids and the expression of adverse side-effects on performance, carcass, and pork quality. The 4 treatments were $0 \%$ tuna oil in diet (T0; control), $1 \%$ of unrefined tuna oil in diet fed from 35 to $90 \mathrm{~kg}$ of BW (T1), and $3 \%$ of unrefined tuna oil in diet offered during the early (35 to $60 \mathrm{~kg}$ of BW; T3-E) or late stage of fattening (75 to $90 \mathrm{~kg}$ of BW; T3-L). With this arrangement, pigs consumed equal lifetime amounts of tuna oil (approximately $1.6 \mathrm{~kg}$ per pig). None of the tuna oil treatments had significant effects on performance. There were no differences in carcass quality among tuna oil groups except for group T3-E where carcasses and loin chops were fatter than those of the other groups. Water-holding capacity and texture of the loin as well as firmness and melting properties of the backfat remained widely unaffected by the treat-
\end{abstract}

ments. Tuna oil feeding resulted in a lighter, less red and less yellow backfat and was found to increase the proportion of n-3 fatty acids to total fatty acids in all treatments. This especially concerned eicosapentaenoic acid and docosahexaenoic acid, but not $\alpha$-linolenic acid. There was also a slight increase in oleic acid, whereas n-6 fatty acids largely decreased. Feeding tuna oil during a short period at the end of fattening (T3-L) or permanently during fattening (T1) proved to be similarly efficient in increasing n-3 fatty acid content of lean and adipose tissue (to about 1.6-fold of T0). By contrast, only two-thirds of this increase was found when the same amount of tuna oil had been fed exclusively during early fattening (T3-E). The decreased efficiency in T3-E was associated with better sensory flavor, overall acceptability grading, and oxidative status. The results show that, particularly under the condition of a continuous supply, much of the n-3 fatty acids ingested in early fattening can be recovered in pork. These findings give farmers flexibility as to when and how pork can be enriched in n-3 fatty acids with fish oil.

Key words: fatty acid, fish oil, n-3, pig, pork, tuna oil

(C)2009 American Society of Animal Science. All rights reserved.

J. Anim. Sci. 2009. 87:693-703 doi:10.2527/jas.2008-0863

\section{INTRODUCTION}

Eicosapentaenoic acid (EPA; C20:5n-3) and docosahexaenoic acid (DHA; C22:6n-3) are considered to be beneficial for human health (Simopoulos, 2002). Pork typically contains only minute amounts of n-3 fatty acids (FA) and is high in n-6 FA (Wood et al., 2003). Its n-6:n-3 FA ratio by far exceeds the recommended value of 5:1 (DACH, 2000). The FA profile of pork is sensitive

\footnotetext{
${ }^{1}$ This study was supported by the Thailand Research Fund (TRF). The authors highly appreciate Agro-1 farm, in collaboration with the Mittraphap Phokaphan Group, Saraburi, Thailand, for the support provided in carrying out the experiment.

${ }^{2}$ Corresponding author: ja.sanchai@gmail.com

Received January 11, 2008.

Accepted October 5, 2008.
}

to dietary FA changes because only few changes occur from feed to tissue (Rosenvold and Andersen, 2003). Marine oils were found to be effective in enriching pork with EPA and DHA (e.g., Leskanich et al., 1997; Azain, 2004), but the search for the ideal strategy is still ongoing. The deposition capacity could be limited because response efficiency was found to decline with increasing dietary fish oil concentrations (Jaturasitha et al., 2002). Still, comparisons of different studies suggest that a short-term high dose of marine oil is very efficient in modifying n-3 concentration in pig adipose tissues (Irie and Sakimoto, 1992; Jaturasitha et al., 2002; Ding et al., 2003; Nguyen et al., 2003); however, effects of a subsequent withdrawal of the oil were not examined. Whole carcass analysis suggested that PUFA, once incorporated in the body, remain there until slaughter (Wenk et al., 1990; Bee and Wenk, 1994). These studies 
only followed intake and recovery of linoleic acid (LA, C18:2n-6) and $\alpha$-linolenic acid (ALA; C18:3n-3), but not EPA and DHA. Lauridsen et al. (1999), feeding fish oil from weaning to $60 \mathrm{~kg}$ of BW, found smaller proportions of EPA and DHA in 100-kg pigs, but it cannot be excluded that this had been exclusively the result of a later dilution by other FA.

The hypothesis tested in the present study was that the efficiency of modification of n-3 FA in meat and fat tissue of pigs by feeding tuna oil is independent of the time within the fattening period and the dosage of tuna oil as long as total intake is constant. Side effects on performance and meat quality were supposed to be similar, too. Based on this, strategies for n-3 FA enrichment of pork might be refined.

\section{MATERIALS AND METHODS}

Fattening and slaughter were carried out according to the standards of Department of Livestock Development, Ministry of Agriculture and Cooperative, Royal Thai Government on a private farm and in a commercial slaughter plant.

\section{Animals and Experimental Treatments}

Six hundred Duroc $\times($ Large White $\times$ Landrace $)$ pigs (one-half of them being barrows and gilts, respectively) were assigned to 4 dietary treatment groups in a completely randomized design and balanced for sex. The pigs were fattened from 35 to $90 \mathrm{~kg}$ of BW. Treatments consisted of control diets without tuna oil (T0), a diet containing $1 \%$ of tuna oil being fed from 35 to $90 \mathrm{~kg}$ of BW (T1; fed for $80 \mathrm{~d}$ on average), or diets containing $3 \%$ of tuna oil offered during the growing period (35 to $60 \mathrm{~kg}$ of BW; T3-E; fed for $30 \mathrm{~d}$ ) or in the late finishing period (75 to $90 \mathrm{~kg}$ of BW; T3-L; fed for $25 \mathrm{~d}$ ). In the respective other periods, pigs of treatments T3-E and $\mathrm{T} 3-\mathrm{L}$ received the tuna oil-free control diet also fed to the control pigs. This arrangement guaranteed that each tuna oil-fed pig, irrespective of treatment, was ingesting approximately the same total amount of tuna oil (target amount: $1.6 \mathrm{~kg}$ ) during fattening. The dietary tuna oil concentrations applied were the same as those used in previous studies (Jaturasitha et al., 2002) and are to be considered as moderate (1\%) to substantial $(3 \%)$ with respect to the range in fat supplementation common in pig feeding (Azain, 2001). The pigs were group housed on concrete floor in pens of 25 pigs. There were a total of 6 pens per treatment, with pigs of different sexes being kept separately. Pigs of all experimental groups received complete diets that were offered in pelleted form. Different diet types were used from 35 to 60,60 to 75 , and 75 to $90 \mathrm{~kg}$ of BW, respectively, to account for the changes occurring in requirements for energy and protein during growth (Ewan, 2001). Unrefined tuna oil (T.C. Union Agrotech Co. Ltd., Bangkok, Thailand), a relatively inexpensive tuna cannery by-product, was chosen for the present experiment because this product is economically viable for pork production. The ingredient composition of the diets (Table 1 ) shows that tuna oil (and rice bran) replaced broken rice and, with $3 \%$ tuna oil, also maize. This procedure ensured that calculated contents of $\mathrm{CP}$ and energy were the same within the feeds designed for the same fattening period. Diets were formulated based on feed tables and energy recommendations (3.30 Mcal of $\mathrm{ME} / \mathrm{kg}$ of diet) of NRC (1998), whereas CP contents were set greater (targets: 20,19 , and $18 \%$ in the 3 fattening periods). Via the commercial vitamin-trace element mix designed for fattening pigs, the concentration of vitamin E supplementation was 3.75 and $5.5 \mathrm{mg} / \mathrm{kg}$ of diet for the growing period (35 to $60 \mathrm{~kg}$ of BW) and the subsequent periods, respectively. The analyzed FA profiles of the unrefined tuna oil and of the complete diets are shown in Table 2. Even supplementation with $3 \%$ of tuna oil left LA as the major dietary PUFA. The marginal increase of the EPA and DHA proportion found in the $3 \%$ tuna oil diet in the growing period could have been related to the concomitantly increased SFA proportion, especially palmitic acid (C16:0) coming from tuna oil. However, this phenomenon did not occur in the late finishing diet. It may have been that different batches used for the feeds with time might have been mainly responsible for this inconsistency. Ether extract contents reflected tuna oil additions in the grower diets, whereas analyses were inconsistent in the finishing diets. However the distinct FA profile (Table 2) clearly demonstrates the presence of tuna oil in the intended proportions (cf. early-fattening diets). The animals were fed at a level that ensured complete feed intake but also guaranteed satiety and had free access to fresh water.

\section{Data and Sample Collection As Well As Analysis}

On Farm Data Collection. Productive performance was measured throughout the fattening period. Daily feed and tuna oil intake per pig was estimated from group consumption, with pens representing the replicates. One-third, randomly selected from all animals, were weighed at fixed dates, and the average BW per pen value was used for ADG and G:F ratio calculations.

Carcass Quality Measurements. At a target level of $90 \mathrm{~kg}$ of BW (realized: $91.3 \mathrm{~kg}$ on average), pigs were slaughtered. Fifty-six animals (14 per dietary treatment; 7 barrows and 7 gilts each) were randomly selected for all further measurements. The carcasses were weighed and then chilled at $3^{\circ} \mathrm{C}$ for $24 \mathrm{~h}$. Afterwards, using the right carcass side, quality variables were determined including dressing percentage, average backfat thickness calculated either from measurements at the first rib, the last rib, and the last lumbar vertebra, or between the 10th and the 11th rib, and lean percentage [using the equation of Jaturasitha (2004) based on carcass weight, assuming $3 \%$ of weight loss 
Table 1. Ingredient composition and analyzed chemical composition (\%) of complete diets used in the 3 experimental periods (as-fed basis)

\begin{tabular}{|c|c|c|c|c|c|c|c|c|}
\hline \multirow[b]{2}{*}{ Item } & \multicolumn{3}{|c|}{$\begin{array}{c}\text { Growing period } \\
(35 \text { to } 60 \mathrm{~kg} \text { of } \mathrm{BW})\end{array}$} & \multicolumn{2}{|c|}{$\begin{array}{l}\text { Early finishing period } \\
(60 \text { to } 75 \mathrm{~kg} \text { of } \mathrm{BW})\end{array}$} & \multicolumn{3}{|c|}{$\begin{array}{l}\text { Final finishing period } \\
\text { (75 to } 90 \mathrm{~kg} \text { of } \mathrm{BW})\end{array}$} \\
\hline & Control & $1 \%$ tuna & 6 tuna oil & Control & $1 \%$ tuna oil & Control & $1 \%$ tuna $\mathrm{o}$ & tuna oil \\
\hline \multicolumn{9}{|l|}{ Ingredient composition } \\
\hline Tuna oil & 0.00 & 1.00 & 3.00 & 0.00 & 1.00 & 0.00 & 1.00 & 3.00 \\
\hline Rice bran & 5.89 & 6.89 & 11.89 & 3.92 & 4.92 & 1.93 & 2.93 & 7.93 \\
\hline Soybean meal & 29.4 & 29.4 & 29.4 & 26.7 & 26.7 & 24.1 & 24.1 & 24.1 \\
\hline Fish meal & 4.00 & 4.00 & 4.00 & 4.00 & 4.00 & 4.00 & 4.00 & 4.00 \\
\hline Rice bran oil & 1.71 & 1.71 & 1.71 & 1.51 & 1.51 & 1.31 & 1.31 & 1.31 \\
\hline Limestone & 1.15 & 1.15 & 1.15 & 1.14 & 1.14 & 1.13 & 1.13 & 1.13 \\
\hline Monodicalcium phosphate & 0.96 & 0.96 & 0.96 & 1.02 & 1.02 & 1.08 & 1.08 & 1.08 \\
\hline Sodium chloride & 0.16 & 0.16 & 0.16 & 0.16 & 0.16 & 0.17 & 0.17 & 0.17 \\
\hline $\mathrm{DM}$ & 89.6 & 89.6 & 90.4 & 89.6 & 90.4 & 89.9 & 89.2 & 89.7 \\
\hline $\mathrm{CP}$ & 20.7 & 21.0 & 21.0 & 19.1 & 21.1 & 19.5 & 19.3 & 19.1 \\
\hline Ether extract & 5.59 & 6.33 & 9.10 & 5.77 & 6.46 & 5.78 & 4.83 & 4.78 \\
\hline
\end{tabular}

Table 2. Analyzed fatty acid profile (\% of total analyzed fatty acids) of tuna oil (TO) and complete diets in the 3 experimental periods

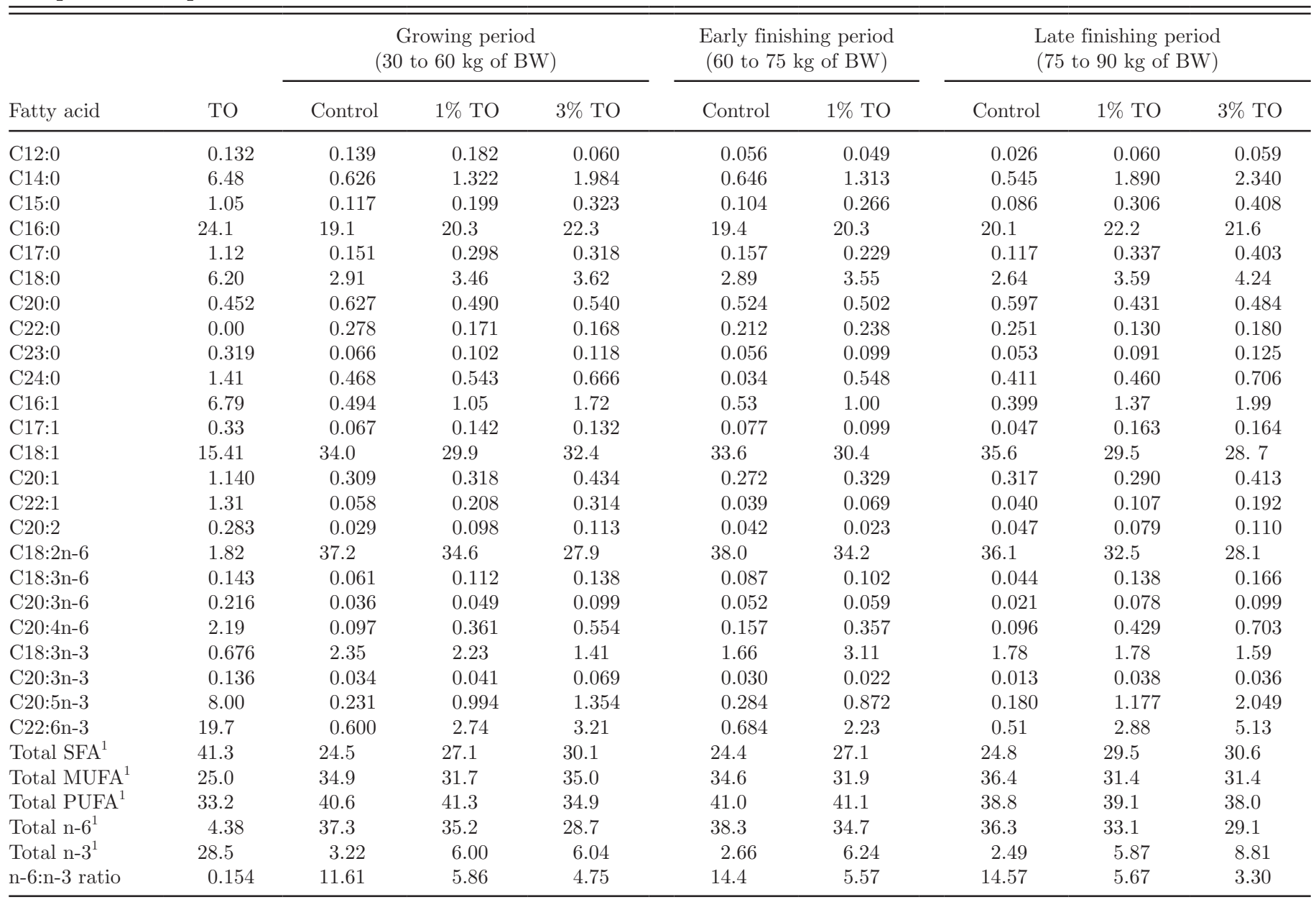

\footnotetext{
${ }^{1}$ Sum of all identified fatty acids of the respective group.
} 
during chilling, backfat thickness at the 10th/11th rib, and loin eye area]. The loin chop of the 10th and the 11th rib was dissected for lean, fat, bone, and skin. The remainder from between the 6th and the 14th rib was separated into LM (loin) and backfat (subcutaneous fat). The LM was cut into slices of 2-cm thickness, whereas the backfat was cut into individual portions for later analysis of the different fat quality variables. Subsequently, some samples were reserved for color and drip loss measurements, whereas all other material was vacuum-packaged and stored at $-20^{\circ} \mathrm{C}$ until further analysis.

Feed, Meat, and Adipose Tissue Analyses. In the complete diets, DM $\left(105^{\circ} \mathrm{C}\right.$ for $\left.3 \mathrm{~h}\right), \mathrm{CP}$ (Kjeldahl), Soxhlet fat, and GE (bomb calorimetry) were determined by standard procedures (AOAC, 1995). In LM, determinations of water-holding capacity included drip loss (as outlined by Honikel and Hamm, 1999). Besides, the frozen LM samples were thawed at $4^{\circ} \mathrm{C}$ for $24 \mathrm{~h}$ and weighed for thawing loss determination. Cooking and grilling loss were carried out in LM samples boiled at $85^{\circ} \mathrm{C}$ in a water bath or grilled in a convection oven at $160^{\circ} \mathrm{C}$ for 15 min, respectively, until the internal temperature reached $70^{\circ} \mathrm{C}$ (standard procedures as described in Jaturasitha, 2004). Shear force was measured using a Warner-Bratzler shear blade attached to a texture analyzer (TA.XT2, Stable Micro System Ltd., Surrey, UK) on 12.5-mm-diameter cores drilled from the boiled LM samples previously cooled to room temperature. A crosshead speed of $200 \mathrm{~mm} / \mathrm{min}$ and a $5 \mathrm{kN}$ load cell, calibrated to read over range of 0 to $490 \mathrm{~N}$, were applied. The meat was also subjected to sensory evaluation as outlined by Viriyajari (1992) after $1 \mathrm{mo}$ of storage at $-20^{\circ} \mathrm{C}$ in a vacuum-packaged form. A panel of 6 trained persons was used for grading tenderness, juiciness, flavor, and overall acceptability applying a scale from 1 to 9 . This was done with grilled LM of each individual of the 56 pigs offered in pieces of a size of $1 \times 1 \times 1 \mathrm{~cm}$. Per session, 12 different meat samples were served to the panelists. Panelists also were invited to note the occurrence of off-flavors or fishy flavor. In LM and backfat, after seal-bagged storage at $4^{\circ} \mathrm{C}$ for $24 \mathrm{~h}$ and subsequent blooming for $1 \mathrm{~h}$ in the refrigerator, lightness $\left(\mathrm{L}^{*}\right)$, redness $\left(\mathrm{a}^{*}\right)$, and yellowness $\left(b^{*}\right)$ were measured with a Lab photometer (Chroma Meter CR-300, Minolta, Tokyo, Japan). In both body tissues (after microwave-assisted extraction of backfat samples), Soxhlet fat (adapted from AOAC, 1995) was determined. Additionally, cholesterol contents were measured by a method adapted from Jung et al. (1975). The thiobarbituric acid (TBA) number was analyzed according to Rossell (1994) in sliced LM and backfat samples cut into 4 pieces and stored separately at $4^{\circ} \mathrm{C}$ in closed plastic bags for $0,3,6$, and $9 \mathrm{~d}$. The extracted backfat was also analyzed for firmness. At first, $10 \mathrm{~mL}$ of the liquid fat was transferred into 15 -mL-size bottles filled $3 \mathrm{~cm}$ high. The fat was allowed to congeal for $45 \mathrm{~min}$ at room temperature and was subsequently kept at $-20^{\circ} \mathrm{C}$ until analysis. Before firm- ness measurement, the samples were stored at $4^{\circ} \mathrm{C}$ for 30 min. Penetrating force was measured with a cylindrically shaped stainless-steel probe $(5 \mathrm{~mm}$ diameter $)$ attached to the same texture analyzer as used for shear force determinations. For measurement of the melting properties, the backfat molten by microwave was filled into capillary tubes (Modulohm A/S, Herlev, Denmark) to reach approximately $1 \mathrm{~cm}$ of height. The capillary end was closed with silicone. Afterwards the tubes were stored at $-20^{\circ} \mathrm{C}$ until analysis. Before the measurement, the capillary tubes were kept at $25^{\circ} \mathrm{C}$ for $10 \mathrm{~min}$ and then put into the analyzer (Melting Point SMP10, Stuart, Barloworld Scientific Ltd., Staffordshire, UK). Temperatures were recorded at the start of melting and when the melting process was completed.

Fatty acid methyl esters (FAME) were prepared as outlined by Morrison and Smith (1964) in lipids extracted from diet and LM samples by chloroform/methanol (2:1 vol/vol) (Folch et al., 1957) and from backfat using microwave-assisted fat extraction. Sathivel et al. (2003) described that this way of fat extraction is possible without an alteration of FA profile and therefore advantageous for fat tissues containing substantial amounts of moisture. Subsequently, FAME were analyzed on a gas chromatograph (GC 14B, Shimadzu, Tokyo, Japan) equipped with a FID detector at injection and detector temperatures of $240^{\circ} \mathrm{C}$. The temperature program was carried out with an initial temperature of $160^{\circ} \mathrm{C}$ held for $2 \mathrm{~min}$. The final temperature was $240^{\circ} \mathrm{C}$ held for $20 \mathrm{~min}$. In between, a temperature gradient was applied with $2^{\circ} \mathrm{C} / \mathrm{min}$ from 160 to $180^{\circ} \mathrm{C}$ and with $4^{\circ} \mathrm{C} / \mathrm{min}$ from 180 to $240^{\circ} \mathrm{C}$. The flow rate of the carrier gas, helium, was $1 \mathrm{~mL} / \mathrm{min}$. A mixed FAME standard (Supelco 37 component, Bellefonte, PA) was used for the identification of FA. Because the standard FA mixture used did not include docosapentaenoic acid (DPA, C22:5n-3), this FA was not included. Individual FA were related to total FAME in calculating FA profile, whereas amounts of individual FA in meat and fat tissue were calculated based on proportions of FA times total fat content (ether extract).

\section{Statistical Analysis}

Data were subjected to ANOVA applying the GLM procedure (SAS Inst. Inc., Cary, NC). Dietary treatment, sex, and dietary treatment $\times$ sex were considered as effects. Multiple comparisons among means were carried out with Tukey's procedure. Sex differences were not displayed in the tables because they did not represent the focus of the study and because the interaction with diet type was rarely significant.

\section{RESULTS}

\section{Effects on Performance, Carcass, Meat, and Fat Tissue Quality}

Growth performance (intake, ADG, and feed conversion ratio) was similar across treatments in all periods 
of fattening (Table 3). There was also only a minor difference among tuna oil treatments in total tuna oil intake per animal. Compared with T0, this was associated with 4.1-, 4.9-, and 2.0-fold greater total intakes of EPA, DHA, and total n-3 FA, respectively. Hot carcass weights from control pigs were less $(P<0.05)$ than those of the 3 tuna oil-supplemented groups; however, there was no difference $(P>0.05)$ in dressing and lean percentages. Pigs of group T3-E had a thicker $(P<$ 0.05) backfat when measured across the entire back than those of the other treatments. Backfat determined at the 10 th/11th rib showed the same trend, but the difference was not statistically significant. Loin chops of the T1 pigs contained more lean and less fat tissue and bones compared with that of the control pigs, whereas this was opposite in T3-E pigs and intermediate in T3-L pigs.

The water-holding capacity of the LM did not differ among treatments in terms of drip, boiling, and grilling loss (Table 3). However, thawing loss was found to be less $(P<0.05)$ in T1 pigs than in T3-E pigs. Shear force and sensory tenderness grading did not differ among groups; this was also true for juiciness. Flavor and acceptability were most favorable in pigs receiving tuna oil in the early fattening period (T3-E), whereas it was less favorable $(P<0.05)$ in those fed tuna oil throughout fattening (T1). However, decreased flavor scoring had not been related to off-flavor or fishy flavor by the panelists. The LM of the T3-L pigs was lightest $(P<0.05$ against the other 2 tuna oil treatments), whereas there was no significant difference in redness and yellowness (Table 4). A clear treatment effect on TBA number of LM was only found after $6 \mathrm{~d}$ of storage when T3-L pigs had greater $(P<0.05)$ values than T3-E pigs, and the others remained intermediate. The TBA number increased with storage time, a trend that was least pronounced in T3-E pigs. Tuna oil feeding did not affect $(P>0.1)$ contents of fat and cholesterol in LM. There was a trend $(P<0.1)$ toward a greater intramuscular fat content in T3-E LM.

The backfat color differed among groups being lighter, less red, and less yellow with any tuna oil supplementation regimen compared with T0 pigs $(P<0.05$ to most groups; Table 4). Also in backfat, the TBA number increased with time, but tuna oil supplementation failed to have significant effects. Backfat cholesterol contents did not differ $(P>0.1)$ among treatments, whereas fat contents were greater $(P<0.05)$ in the pigs fed tuna oil at the end of fattening (T3-L), particularly in relation to T0 and T1. Backfat firmness and melting point were not significantly affected by treatment.

\section{Effects on FA Profile and n-3 FA Deposition in Lean and Adipose Tissue}

The proportion of individual (except C24:0 in backfat) and total SFA of total FA in LM and backfat lipids remained unaffected $(P>0.1)$ by any of the tuna oil treatments (Table 5). Short-term increased doses of tuna oil in the diet (T3-E and T3-L) elevated $(P<$ $0.05)$ proportions of MUFA and, more specifically, of C16:1 (significant only in LM) and C18:1 compared with control, whereas this change was smaller in T1. As expected, tuna oil supplementation elevated $(P<0.05)$ the proportions of total n-3 FA, EPA, and DHA, whereas there was no noticeable change in ALA proportion. There were, however, also differences between tuna oil groups, with the pigs receiving tuna oil only during early fattening (T3-E) tending to have less increase in the proportion of these FA relative to $\mathrm{T} 0$ in both body tissues when compared with the enhancements found in T3-L and T1. In the latter 2 groups, increases relative to control in total n-3 FA, EPA, and DHA proportions were on average 1.40-, 2.13-, and 1.34-fold of control in LM lipids and 1.52-, 2.92-, and 2.62-fold in backfat, respectively. The corresponding values found in T3-E were less than one-half in LM (1.15-, 1.58-, and 1.08fold) and slightly more than one-half in backfat (1.34-, $2.00-$, and 2.07-fold). In compensation to the shifts in n-3 FA proportions, there was a decline in proportions of n-6 FA in general and especially in the 2 major individual n-6 FA, LA and arachidonic acid (C20:4n-6; only LM). Consequently, the n-6:n-3 ratio was greatest in control, whereas the ratio was reduced $(P<0.05)$ to about one-half of T0 in T1 and T3-L. Ratios found in T3-E were intermediate and differed $(P<0.05)$ from all other groups in both tissues. Despite the increased PUFA content of the tuna oil-supplemented diets, the overriding effect concerning FA group proportions was still a reduction in PUFA with tuna oil due to a compensatory increase in MUFA (C18:1).

The effects of the tuna oil feeding regimen differed to some extent when n-3 FA content of the LM and the backfat was calculated (Table 6). This was due to associated changes in fat content of the tissues. Accordingly, exclusive early tuna oil feeding (T3-E) was actually more efficient in elevating n-3 FA in lean tissue as had been apparent from FA profile. Increases relative to control were 1.62- and 1.40-fold with T1/T3-L and T3-E, respectively. On a content basis, the corresponding differences in efficiency of n-3 FA deposition were quite similar in adipose tissue (1.61- vs. 1.36-fold increase relative to control) to that found in LM.

\section{DISCUSSION}

\section{Strategic Enrichment of Pork with n-3 FA by Feeding Tuna Oil}

The highly unsaturated FA, EPA and DHA, are considered to be particularly beneficial in preventing cardiovascular and inflammatory diseases as well as cancer (Simopoulos, 2002). The shorter chain n-3 FA, ALA, is valuable, too, but is less efficient in that respect (Simopoulos, 2000). Typically, pork contains few n-3 FA and is rich in n-6 FA, especially LA (Wood et al., 2003). This triggered research for strategically enriching pork with n-3 FA. Sources of n-3 FA include flaxseed, linseed, and 
canola (e.g., Romans et al., 1995; Soler-Velasquez et al., 1998; Kouba et al., 2003), but ALA is the major n-3 FA supplied. In pigs, and even less so in humans, only approximately one-third of deposited ALA can be converted to EPA and DPA, and to a smaller extent, DHA (Kloareg et al., 2007). Accordingly, sources of EPA and DHA such as marine oils are much more effective for the enrichment of these FA in pork (e.g., Leskanich et al., 1997; Azain, 2004).
The type and level of effect in enriching EPA and DHA in lean and adipose tissue by the equivalent of $1 \%$ tuna oil in the diet throughout fattening, as found in the present study, was similar to earlier findings (Jaturasitha et al., 2002), whereas the use of 0.2 to $0.4 \%$ fish oil was reported to have only minor effects (Bryhni et al., 2002). The enrichment of the tissues with EPA, DHA, and total n-3 PUFA achieved was substantial (1.3- to 2.9-fold compared with that of control). The de-

Table 3. Intake, ${ }^{1}$ BW gains, carcass, and meat quality of pigs fed no tuna oil or tuna oil in different growth periods

\begin{tabular}{|c|c|c|c|c|c|c|}
\hline \multirow[b]{3}{*}{ Item } & Treatment 0 & Treatment 1 & Treatment 3-E & Treatment 3-L & \multirow[b]{3}{*}{ SEM } & \multirow[b]{3}{*}{$P$-value } \\
\hline & $0 \%$ tuna oil & $1 \%$ tuna oil & $3 \%$ tuna oil & $3 \%$ tuna oil & & \\
\hline & $\begin{array}{l}35-90 \mathrm{~kg} \\
\text { target } \mathrm{BW}\end{array}$ & $\begin{array}{l}35-90 \mathrm{~kg} \\
\text { target } \mathrm{BW}\end{array}$ & $\begin{array}{l}35-60 \mathrm{~kg} \\
\text { target } \mathrm{BW}\end{array}$ & $\begin{array}{l}75-90 \mathrm{~kg} \\
\text { target } \mathrm{BW}\end{array}$ & & \\
\hline Initial BW, kg & 37.2 & 35.5 & 34.8 & 35.9 & 0.85 & 0.28 \\
\hline \multicolumn{7}{|l|}{ Feed intake, $\mathrm{kg} / \mathrm{pig} \cdot \mathrm{d}$ (as fed) } \\
\hline 35 to $60 \mathrm{~kg}$ of BW & 1.70 & 1.69 & 1.76 & 1.64 & 0.019 & 0.40 \\
\hline 60 to $75 \mathrm{~kg}$ of $\mathrm{BW}$ & 2.10 & 2.05 & 2.31 & 1.95 & 0.039 & 0.10 \\
\hline 75 to $90 \mathrm{~kg}$ of $\mathrm{BW}$ & 2.24 & 2.31 & 2.26 & 2.22 & 0.042 & 0.93 \\
\hline 35 to $90 \mathrm{~kg}$ of $\mathrm{BW}$ & 1.99 & 2.00 & 2.08 & 1.92 & 0.031 & 0.52 \\
\hline \multicolumn{7}{|l|}{ Total intake } \\
\hline Feed, kg/pig & 155 & 160 & 164 & 148 & 2.5 & 0.27 \\
\hline Tuna oil, kg/pig & $0^{\mathrm{b}}$ & $1.60^{\mathrm{a}}$ & $1.59^{\mathrm{a}}$ & $1.66^{\mathrm{a}}$ & 0.018 & $<0.001$ \\
\hline $\mathrm{C} 20: 5 \mathrm{n}-3, \mathrm{~g} / \mathrm{pig}$ & $17^{\mathrm{b}}$ & $63^{\mathrm{a}}$ & $64^{\mathrm{a}}$ & $67^{\mathrm{a}}$ & 0.8 & $<0.001$ \\
\hline C20:6n-3, g/pig & $43^{\mathrm{b}}$ & $154^{\mathrm{a}}$ & $146^{\mathrm{a}}$ & $159^{\mathrm{a}}$ & 1.8 & $<0.001$ \\
\hline Total n-3, g/pig & $161^{\mathrm{b}}$ & $329^{\mathrm{a}}$ & $321^{\mathrm{a}}$ & $315^{\mathrm{a}}$ & 4.2 & $<0.001$ \\
\hline \multicolumn{7}{|l|}{$\mathrm{ADG}, \mathrm{g} / \mathrm{pig}$} \\
\hline 35 to $60 \mathrm{~kg}$ of $\mathrm{BW}$ & 801 & 836 & 841 & 835 & 14.5 & 0.85 \\
\hline 60 to $90 \mathrm{~kg}$ of $\mathrm{BW}$ & 548 & 629 & 683 & 654 & 20.4 & 0.29 \\
\hline 35 to $90 \mathrm{~kg}$ of $\mathrm{BW}$ & 645 & 707 & 743 & 725 & 11.6 & 0.12 \\
\hline \multicolumn{7}{|c|}{$\begin{array}{l}\text { Feed conversion ratio, } \mathrm{kg} \text { of gain } / \mathrm{kg} \\
\text { of feed }\end{array}$} \\
\hline 35 to $60 \mathrm{~kg}$ of $\mathrm{BW}$ & 0.470 & 0.590 & 0.485 & 0.513 & 0.0098 & 0.57 \\
\hline 60 to $90 \mathrm{~kg}$ of $\mathrm{BW}$ & 0.253 & 0.288 & 0.310 & 0.314 & 0.0110 & 0.40 \\
\hline 35 to $90 \mathrm{~kg}$ of $\mathrm{BW}$ & 0.324 & 0.354 & 0.366 & 0.380 & 0.0082 & 0.28 \\
\hline Slaughter weight, kg & 87.9 & 91.6 & 93.6 & 92.1 & 0.93 & 0.17 \\
\hline $\mathrm{HCW}, \mathrm{kg}$ & $65.9^{\mathrm{b}}$ & $72.9^{\mathrm{a}}$ & $73.9^{\mathrm{a}}$ & $72.3^{\mathrm{a}}$ & 0.73 & 0.001 \\
\hline \multicolumn{7}{|l|}{ Carcass quality } \\
\hline Dressing percentage & 73.0 & 77.2 & 76.6 & 76.6 & 0.57 & 0.05 \\
\hline Lean percentage & 60.2 & 60.7 & 59.5 & 59.7 & 0.35 & 0.62 \\
\hline \multicolumn{7}{|l|}{ Backfat thickness, cm } \\
\hline Across entire length & $1.94^{\mathrm{b}}$ & $2.19^{\mathrm{b}}$ & $2.76^{\mathrm{a}}$ & $2.36^{\mathrm{b}}$ & 0.052 & $<0.001$ \\
\hline Between 10th/11th rib & 1.43 & 1.56 & 1.95 & 1.74 & 0.070 & 0.06 \\
\hline \multicolumn{7}{|l|}{ Loin chop composition, \% } \\
\hline Lean & $64.4^{\mathrm{ab}}$ & $66.2^{\mathrm{a}}$ & $60.0^{\mathrm{b}}$ & $62.1^{\mathrm{ab}}$ & 0.66 & 0.010 \\
\hline Fat & 13.7 & 14.4 & 17.8 & 17.2 & 0.64 & 0.07 \\
\hline Bone & $17.4^{\mathrm{ab}}$ & $14.7^{\mathrm{b}}$ & $17.7^{\mathrm{a}}$ & $15.8^{\mathrm{ab}}$ & 0.38 & 0.02 \\
\hline Skin & 4.5 & 4.6 & 4.4 & 4.8 & 0.14 & 0.81 \\
\hline \multicolumn{7}{|l|}{ LM water-holding capacity } \\
\hline Drip loss, $\%$ & 5.70 & 4.12 & 4.72 & 5.43 & 0.315 & 0.29 \\
\hline Thawing loss, \% & $13.9^{\mathrm{a}}$ & $8.77^{\mathrm{b}}$ & $14.3^{\mathrm{a}}$ & $11.3^{\mathrm{ab}}$ & 0.49 & 0.001 \\
\hline Boiling loss, $\%$ & 20.0 & 21.6 & 21.6 & 19.8 & 0.83 & 0.80 \\
\hline Grilling loss, \% & 28.0 & 25.7 & 26.0 & 25.9 & 0.71 & 0.63 \\
\hline LM shear force, $\mathrm{N}$ & 29.8 & 36.4 & 36.3 & 33.4 & 1.50 & 0.26 \\
\hline \multicolumn{7}{|l|}{ LM panel score ${ }^{2}$} \\
\hline Tenderness & 5.40 & 5.21 & 5.51 & 5.51 & 0.010 & 0.72 \\
\hline Juiciness & 5.13 & 5.51 & 5.40 & 5.64 & 0.087 & 0.21 \\
\hline Flavor & $6.25^{\mathrm{ab}}$ & $5.86^{\mathrm{b}}$ & $6.36^{\mathrm{a}}$ & $5.96^{\mathrm{ab}}$ & 0.056 & 0.008 \\
\hline Overall acceptability & $5.79^{\mathrm{ab}}$ & $5.68^{\mathrm{b}}$ & $6.18^{\mathrm{a}}$ & $5.80^{\mathrm{ab}}$ & 0.062 & 0.02 \\
\hline
\end{tabular}

${ }^{\mathrm{a}, \mathrm{b}}$ Within a row, means without a common superscript letter are different at $P<0.05$.

${ }^{1}$ Estimated from pen group consumption data.

${ }^{2} 1=$ judged extremely unfavorable; $9=$ judged extremely favorable. 
gree of unsaturation was still smaller than when feeding the control diet due to decreased PUFA, especially LA, and greater MUFA proportions. Overall, this caused the $\mathrm{n}-6: \mathrm{n}-3$ ratio to get reduced to an even larger extent compared with what would have been expected from the changes in n-3 FA alone. The human-health-related threshold in n-6:n-3 of $<5: 1$ recommended by an association of nutrition societies of German-speaking countries (DACH, 2000) or the range of 1:1 to 4:1 suggested by Simopoulos (2002) was still not reached in both tissues with any tuna oil supplementation, but was at least approached by T1 and T3-L. However, the values were far from the unfavorably high n-6:n-3 ratio of 15:1 to 17:1 common in Western diets (Simopoulos, 2002).

Gebauer et al. (2006) stated that approximately 500 $\mathrm{mg} / \mathrm{d}$ of EPA and DHA intake are necessary to reduce the risk of cardiovascular diseases in human and $1 \mathrm{~g} / \mathrm{d}$ when the disease has already developed. When relating this with our results, $100 \mathrm{~g}$ of n-3 enriched lean pork supplied up to $22 \mathrm{mg}$ of EPA and DHA, compared with $14 \mathrm{mg}$ in the control pork. The corresponding values for $100 \mathrm{~g}$ of backfat were about 778 vs. $254 \mathrm{mg}$. A meat product made of lean and adipose tissue from tuna-oil fed pigs in proportions of 1:1 would therefore contribute about two-thirds of the recommended intake and, compared with control pork, an extra amount of almost $250 \mathrm{mg} / \mathrm{d}$ of EPA and DHA.

\section{Importance of the Period of Feeding Tuna Oil on n-3 FA Deposition in Pork}

The present study investigated the ideal period of supplementation of tuna oil to enrich n-3 FA in lean and fat tissue of pigs. Actually, there is a certain time component in the incorporation of EPA and DHA in fat from pigs fed fish oil. In the study of Irie and Sakimoto (1992), a plateau in EPA and DHA needed 2 to 3 wk to develop after starting of fish oil feeding. For total C18 PUFA, Warnants et al. (1999) reported the largest changes in incorporation and elimination in backfat to occur within the first $2 \mathrm{wk}$ and a plateau to be reached after $6 \mathrm{wk}$. This means that in any of the present shortterm treatments (tuna oil feeding in T3-E and T3-L lasted for 3 to $4 \mathrm{wk}$ ), a plateau should have developed. There is also the aspect of continuous shifts among body tissues where accretion during growth preferentially takes place. With increasing BW (especially $>80$ $\mathrm{kg}$ of BW), body fat accretion of pigs is enhanced at the expense of other compounds, especially protein (De Lange et al., 2001). Likewise, Azain (2001) quantified fat deposition during the finishing phase to be ranging from 250 to $450 \mathrm{~g} / \mathrm{d}$, and this primarily in adipose tissue, whereas in the suckling phase lipid deposition ranges from 30 to $50 \mathrm{~g} / \mathrm{d}$, similar to protein deposition. Finally, Irie and Sakimoto (1992) demonstrated that EPA and DHA can be massively elevated by feeding fish oil to pigs for 2 to $4 \mathrm{wk}$ before slaughter.

In the present study, a decreased concentration of tuna oil in the diet (1\%), fed for the entire fattening

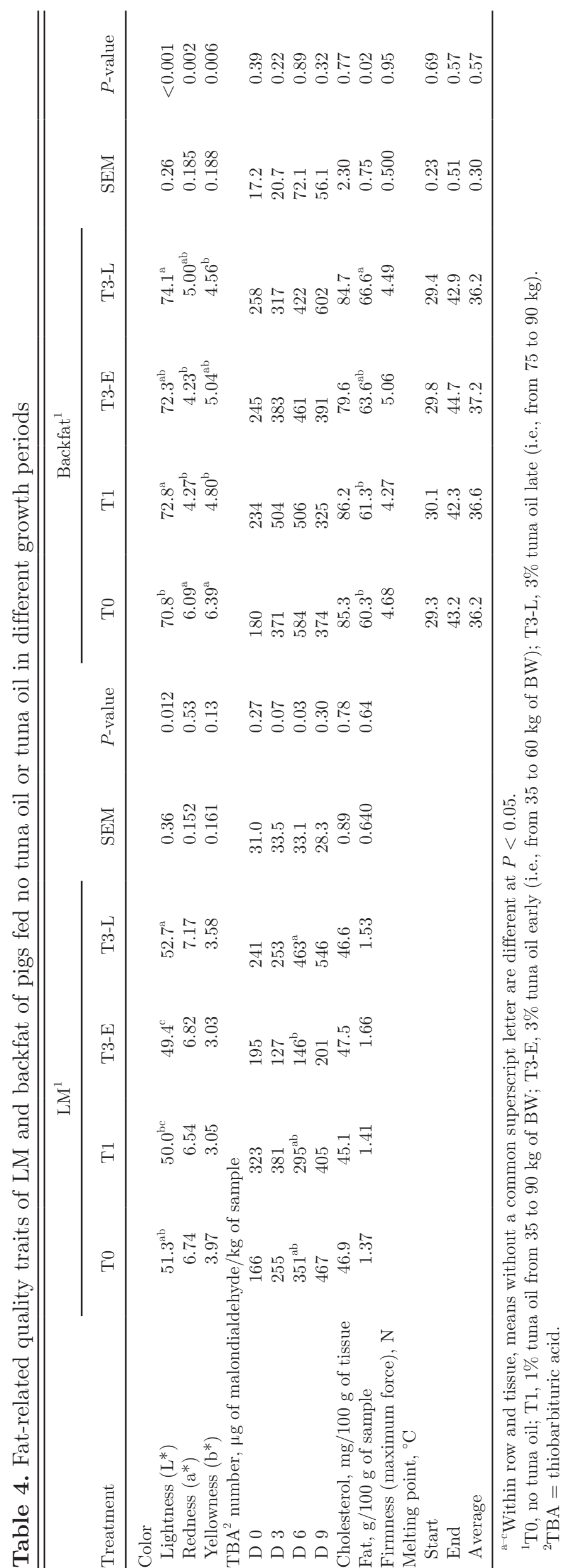




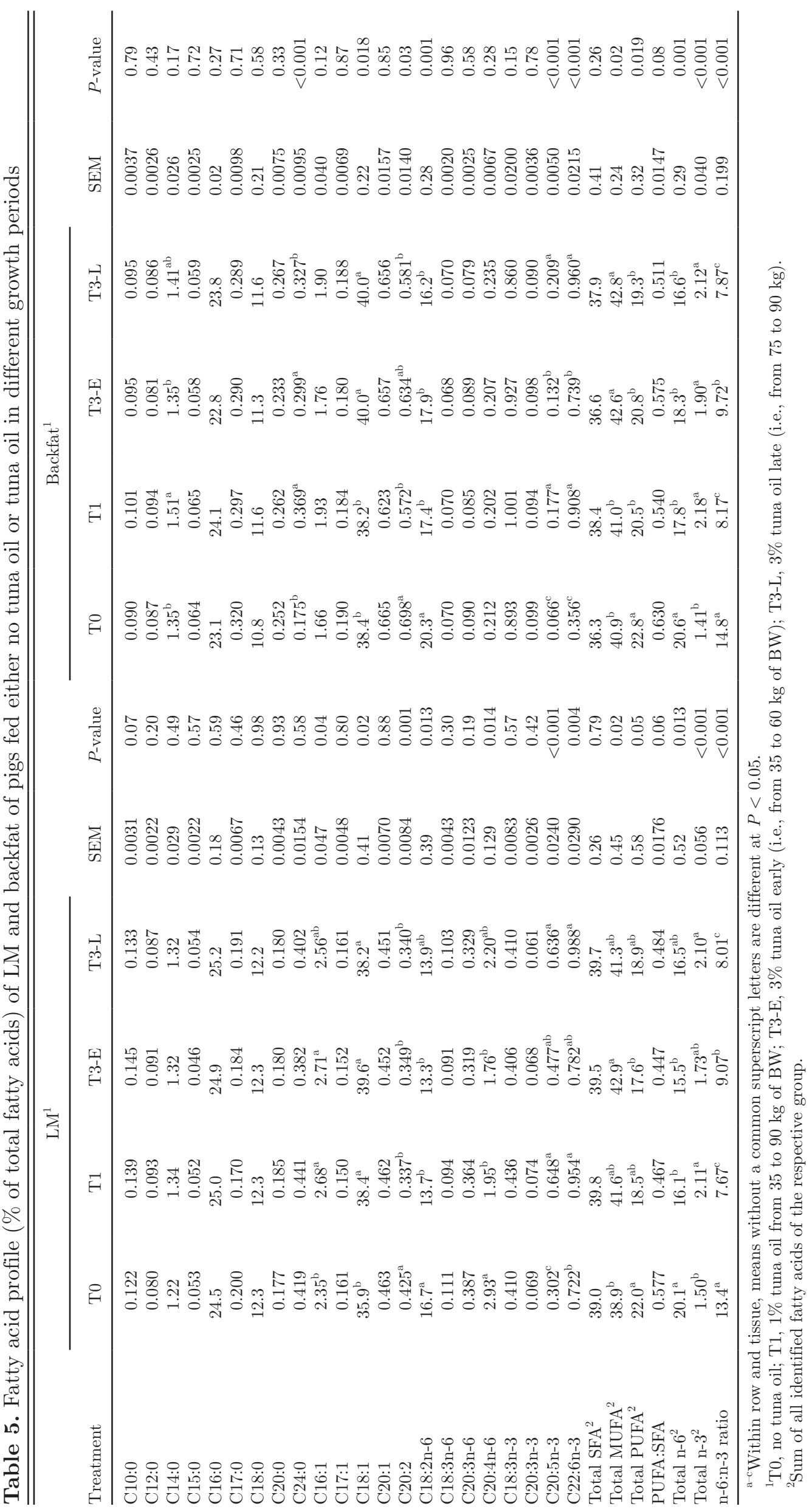


Table 6. Content of $n-3$ fatty acids (mg/100 g of wet weight) of LM and backfat of pigs fed no tuna oil or tuna oil in different growth periods

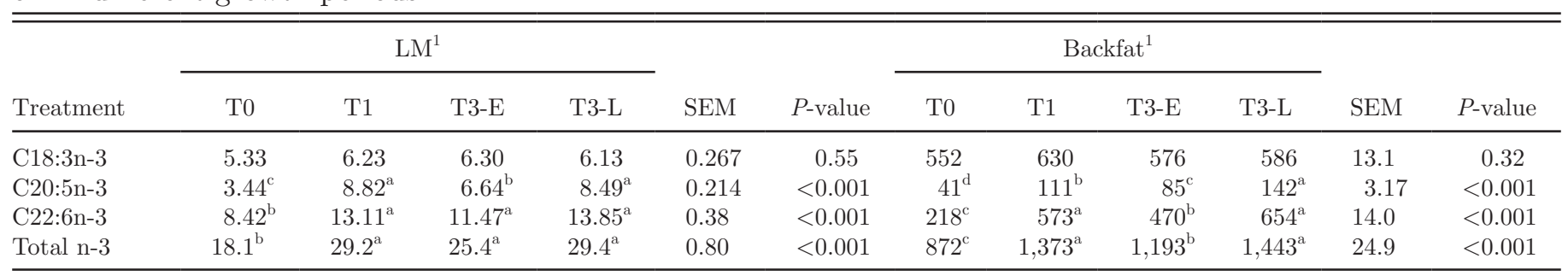

${ }^{\mathrm{a}-\mathrm{d}}$ Within row and tissue, means without a common superscript letters are different at $P<0.05$.

${ }^{1}$ T0, no tuna oil; T1, $1 \%$ tuna oil from 35 to $90 \mathrm{~kg}$ of BW; T3-E, 3\% tuna oil early (i.e., from 35 to $60 \mathrm{~kg}$ of BW); T3-L, $3 \%$ tuna oil late (i.e., from 75 to $90 \mathrm{~kg})$.

period, still was found to be similarly effective as the larger quantity of tuna oil (3\%) applied in the period before slaughter. However, when the increased concentration of tuna oil was fed at the start of the fattening period, the final n-3 FA proportions in total lipids and contents in meat and backfat were less. To our knowledge, these phenomena have not yet been described before. The decline in n-3 FA proportion reported by Lauridsen et al. (1999) in pigs after withdrawal fish oil from 60 to $100 \mathrm{~kg}$ of $\mathrm{BW}$ could have been simply an effect of dilution with newly accreted FA. In exchanging fish oil with linseed oil (Haak et al., 2008), chain elongation of ALA originating from linseed cannot be excluded, which also limits comparability with the present study. The T3-E data indicate a certain exchange of n-3 FA stored in the body after tuna oil is withdrawn, whereas this seems not to happen when tuna oil is permanently supplied (T1). The findings of Jaturasitha et al. (2002) rule out that this was simply a matter of reaching the maximum incorporation of n- $3 \mathrm{FA}$ already with $1 \%$ tuna oil because they found clear further increases when permanently feeding diets containing 2 and $3 \%$ tuna oil (the latter only in backfat). Although part of the n-3 FA might be subject to $\beta$-oxidation, it also seems unlikely that these FA are required as a major source of energy because the pigs should have been in an anabolic state all the time. Haak et al. (2008) stated that, compared with ALA, the long-chain n-3 FA are more selectively incorporated into phospholipids of cell structures, resulting in less $\beta$-oxidation. In metabolism, EPA is utilized for the synthesis of eicosanoids, which have a function in hormones and the immune system and can be a substrate for longer chain n-3 FA synthesis in body, whereas DHA is needed for various biochemical functions (Spector, 1999). An expenditure of EPA and DHA without continuous replacement by tuna oil intake in the withdrawal period could therefore be a reason for the decreased EPA and DHA content in T3-E pig tissues. The difference between this group and the other tuna oil-supplemented groups appears to have been larger when looking at the FA profile of the LM compared with that found in the backfat, but this observation obviously was simply the result of a more extensive dilution of $\mathrm{n}-3 \mathrm{FA}$ in LM than in backfat in that group as can be seen from similar differences in FA contents in the tissues. It is, however, puzzling why the group receiving tuna oil at a concentration of $1 \%$ throughout fattening did not show this pattern or at least expressed values intermediate to groups T3-E and T3-L. Obviously, a continuous supply of n-3 FA prevented a net tissue depletion, either by immediately replacing released n-3 FA or by preventing their mobilization at all. The whole-body FA deposition study made by Kloareg et al. (2007) showed that only 0.40 of the digested n-3 FA were deposited and only one-third of the long chain n-3 FA resulted from the conversion of the deposited ALA. Different from Wenk et al. (1990) as well as Bee and Wenk (1994), the present study did not include complete body compositional assessments, which is why only speculations about the fate of the ingested n-3 FA can be made. Accordingly, it seems that, under the condition that the tuna oil supply is not terminated before slaughter, a more or less complete recovery in the body of these essential FA is actually possible as suggested by the earlier findings with shorter-chain-length PUFA (Wenk et al., 1990; Bee and Wenk, 1994). Additionally, tuna oil supplementation regimens did not affect n-3 FA deposition in the 2 body tissues differently, which is unexpected because one tissue (backfat) mainly consisted of depot (neutral) lipids and the other one (LM) likely contained a considerable proportion of functional (polar) lipids, with the latter typically being characterized by greater PUFA proportions than depot lipids (Bee et al., 2002).

\section{Importance of the Period of Feeding Tuna Oil for the Expression of Side Effects}

In the present study, the substitution of starchy feeds by tuna oil in different feeding periods did not significantly affect intake, ADG, and feed conversion ratio. This is consistent with earlier findings when feeding fish oil (e.g., Leskanich et al., 1997; Bryhni et al., 2002; Jaturasitha et al., 2002; Liu et al., 2003). As expected, there was no effect of the period of feeding tuna oil on performance and carcass quality, with carcass fatness as the only exception. The group of pigs receiving an increased concentration of tuna oil at the start of fattening had a $20 \%$ greater backfat thickness (both measures), $13 \%$ more fat tissue in lean, and $13 \%$ great- 
er intramuscular fat contents than pigs of the 2 other tuna oil-supplemented groups. This might have been the result of involuntary genetic differences among pigs allocated to the 3 groups or of an increased fat accretion triggered by the early supplementation of tuna oil. Apart from the slightly greater GE content of the $3 \%$ tuna oil diet in the growing period, there was a trend for a greater feed intake in the period directly following tuna oil supplementation (60 to $75 \mathrm{~kg}$ of BW), but reasons for such metabolic carryover effects when returning to fish oil-free feeding are subject to speculation. Further studies will have to prove or disprove the presence of such a phenomenon.

Effects on meat and fat tissue quality of tuna oil in general, or specified into different supplementations regimens, were small for most properties. This included water-holding capacity, shear force, sensory tenderness and juiciness, cholesterol contents, backfat firmness, and melting properties. In the study of Irie and Sakimoto (1992), supplementing 2 to $6 \%$ fish oil to basal diet, increased iodine number and decreased fat firmness but did not affect melting temperature of the fat. Similarly, Leskanich et al. (1997) found no effect of the use of a 2:1 mixture of rapeseed oil and fish oil on melting temperature of backfat. The lack of effects on fat firmness and melting properties in the present study was probably the result of a generally small dose and, additionally, of the unchanged proportion of SFA. Even changes in MUFA and PUFA proportions had been low in magnitude.

It is well-known (Lauridsen et al., 1999; Sheard et al., 2000; Howe et al., 2002; Jaturasitha et al., 2002) that, in a dose-dependent manner, tuna oil adversely affects fat shelf life, flavor (creating fishy off-flavor) and, with that, overall acceptability of pork made from tuna oilfed pigs. These variables are related because the fishy off-flavor results at least partially from the increased oxidative susceptibility of the highly unsaturated very long chain n-3 PUFA (Jonsdottir et al., 2003). A strategic search is ongoing concerning the identification of the ideal proportion of tuna oil with maximum effect on n-3 FA incorporation at still acceptable pork flavor and oxidative susceptibility. It seems that $1 \%$ of tuna oil in diet across the entire fattening causes only few problems in that respect, whereas greater concentrations trigger consumer complaints (Lauridsen et al., 1999; Jaturasitha et al., 2002). In the present study, none of the trained panelists associated a decreased flavor score with off-flavor and fishy flavor, but the treatment where tuna oil was supplied in early fattening was superior to the other regimens in shelf life and scores given for sensory flavor and overall acceptability. Withdrawal of fish oil supplements before slaughter has been recommended earlier. In a very early study (Fraser et al., 1934), terminating supply 4 wk before slaughter was reported to remove the occurrence of fishy taste from pork. Melton (1990) suggested that at least 2 wk before slaughter are required to prevent a fishy off-flavor in pork. In our study, T3-E pigs received no tuna oil for on average $7 \mathrm{wk}$ before slaughter and side effects of tuna oil were least, but this was accomplished only at cost of a certain loss of n-3 FA. It remains still open whether this was exclusively the result of the decreased recovery of n-3 FA in the meat and fat or, additionally, of the more pronounced dilution by other, less problematic FA in these pigs being fatter than pigs of the other groups.

Another general effect of tuna oil, irrespective of the feeding regimen, was the particularly white fat tissue. There was a certain dilution of feeds rich in carotenoids (corn) by tuna oil, but this shift was very small, making this unlikely as an explanation. Irie and Sakimoto (1992) reported the absence of the yellow fat syndrome in pigs fed diets containing $6 \%$ fish oil; however, this was accomplished only by the addition of sufficient extra vitamin E. It could have been that the tuna oil FA suppressed the incorporation of those FA from the diet with which color active substances might have been associated.

In conclusion, strategies to enrich pork with EPA and DHA and to reduce the n-6:n-3 FA ratio should take advantage of the finding that a reduced concentration of unrefined tuna oil in the diet (1\%) supplied across fattening is similarly efficient as feeding the same amount of tuna oil exclusively in the late finishing period. The presence of adverse side effects was small, but still noticeable. Therefore, the use of extra dietary vitamin E might be helpful (Leskanich et al., 1997). Alternatively, terminating tuna oil feeding sufficiently long before slaughter could be recommended. However, the loss of n-3 in that period is substantial. The latter finding only partially supports the hypothesis that PUFA, once stored in the body of fattening pigs, remain there unchanged. Because differences among overall regimens were limited, farmers get flexibility as to when and how pork shall be enriched in n-3 FA with fish oil, and situations when tuna oil is inexpensive could be strategically utilized.

\section{LITERATURE CITED}

AOAC. 1995. Official Methods of Analysis. 16th ed. Assoc. Off. Anal. Chem., Arlington, VA.

Azain, M. J. 2001. Fat in swine nutrition. Pages 95-105 in Swine Nutrition. A. J. Lewis and L. L. Southern, ed. CRC Press LLC, Boca Raton, FL.

Azain, M. J. 2004. Role of fatty acids in adipocyte growth and development. J. Anim. Sci. 82:916-924.

Bee, G., S. Gebert, and R. Messikommer. 2002. Effect of dietary energy supply and fat source on the fatty acid pattern of adipose and lean tissues and lipogenesis in the pig. J. Anim. Sci. 80:1564-1574.

Bee, G., and C. Wenk. 1994. Effect of soybean-oil and beef-tallow supplementation to pig diets on the fatty acid profile of body lipids. J. Anim. Physiol. Anim. Nutr. (Berl.) 71:277-288. (in German).

Bryhni, E. A., N. P. Kjos, R. Ofstad, and M. Hunt. 2002. Polyunsaturated fat and fish oil diets for growing-finishing pigs: Effects on fatty acid composition and meat, fat, and sausage quality. Meat Sci. 62:1-8.

DACH. (German. Austrian and Swiss Societies of Nutrition). 2000. Referenzwerte für die Nährstoffzufuhr. Umschau Braus, Frankfurt/Main, Germany. 
De Lange, C. F. M., S. H. Birkett, and P. C. H. Morel. 2001. Protein, fat, and bone tissue growth in swine. Pages 64-81 in Swine Nutrition. A. J. Lewis and L. L. Southern, ed. CRC Press LLC, Boca Raton, FL.

Ding, S.-T., A. Lapillonne, W. C. Heird, and H. J. Mersmann. 2003. Dietary fat has minimal effect on fatty acid metabolism transcript concentration in pigs. J. Anim. Sci. 81:423-431.

Ewan, R. C. 2001. Energy utilization in swine nutrition. Pages 85-94 in Swine Nutrition. A. J. Lewis and L. L. Southern, ed. CRC Press LLC, Boca Raton, FL.

Folch, J., M. Lee, and G. H. S. Stanley. 1957. A simple method for the isolation and purification of total lipids from animal tissues. J. Biol. Chem. 226:497-509.

Fraser, E. B., J. H. Stathart, and H. S. Gutteridge. 1934. Fish meals and oils: Feeding value for livestock and poultry. Domest. Can. Dep. Agric. Pamphlet 163:7-10.

Gebauer, S. K., T. L. Psota, W. S. Harris, and P. M. Kris-Etherton. 2006. n-3 Fatty acid dietary recommendations and food sources to achieve essentiality and cardiovascular benefits. Am. J. Clin. Nutr. 83:1526S-1535S.

Haak, L., S. De Smet, D. Fremuat, K. Van Walleghem, and K. Raes. 2008. Fatty acid profile and oxidative stability of pork as influenced by duration and time of dietary linseed or fish oil supplementation. J. Anim. Sci. 86:1418-1425.

Honikel, K. O., and R. Hamm. 1999. Measurement of water holding capacity and juiciness. Pages 125-161 in Quality Attributes and Their Measurements in Meat, Poultry and Fish Products. A. M. Pearson and T. R. Dutson, ed. Aspen Publ. Inc., Gaithersburg, MD.

Howe, P. R. C., J. A. Downing, B. F. S. Grenyer, E. M. GrigonisDeane, and L. Bryden. 2002. Tuna fishmeal as a source of DHA for n-3 PUFA enrichment of pork, chicken, and eggs. Lipids $37: 1067-1076$.

Irie, M., and M. Sakimoto. 1992. Fat characteristics of pigs fed fish oil containing eicosapentaenoic and docosahexaenoic acids. J. Anim. Sci. 70:470-477.

Jaturasitha, S. 2004. Meat Management. 3rd ed. Ming Muang Press, Chiang Mai, Thailand.

Jaturasitha, S., Y. Wudthithumkanaporn, P. Rurksasen, and M. Kreuzer. 2002. Enrichment of pork with omega-3 fatty acids by tuna oil supplements: Effect on performance as well as sensory, nutritional and processing properties of pork. Asian-australas. J. Anim. Sci. 15:1622-1633.

Jonsdottir, R., T. Valdimarsdottir, B. Baldursdottir, and G. Thorkelsson. 2003. Influence of low fat fish meal on fatty acid composition and sensory quality of pork. J. Muscle Foods 14:51-65.

Jung, D. H., H. G. Biggs, and W. R. Moorehead. 1975. Colorimetry of serum cholesterol with use of ferric acetate uranyl acetate and ferrous sulfate/sulfuric acid agents. Clin. Chem. 21:15261530 .

Kloareg, M., J. Noblet, and J. van Milgen. 2007. Deposition of dietary fatty acids, de novo synthesis and anatomical partitioning of fatty acids in finishing pigs. Br. J. Nutr. 97:35-44.

Kouba, M., M. Enser, F. M. Whittington, G. R. Nute, and J. D. Wood. 2003. Effect of a high-linolenic acid diet on lipogenic activities, fatty acid composition, and meat quality in the growing pig. J. Anim. Sci. 81:1967-1979.

Lauridsen, C., G. Andersen, M. Andersson, V. Danielsen, R. Engberg, and K. Jakobsen. 1999. Effect of dietary fish oil supplied to pigs from weaning to $60 \mathrm{~kg}$ liveweight on performance, tissue fatty acid composition and palatability of pork when slaughtered at $100 \mathrm{~kg}$ liveweight. J. Anim. Feed Sci. 8:441-456.

Leskanich, C. O., K. R. Matthews, C. C. Warkup, R. C. Noble, and M. Hazzledine. 1997. The effect of dietary oil containing (n-3) fatty acids on the fatty acid, physicochemical, and organoleptic characteristics of pig meat and fat. J. Anim. Sci. 75:673-683.

Liu, Y. L., D. F. Li, L. M. Gong, G. F. Yi, A. M. Gaines, and J. A. Carroll. 2003. Effect of fish oil supplementation on the performance and the immunological, adrenal, and somatotropic responses of weaned pigs after an Escherichia coli lipopolysaccharide challenge. J. Anim. Sci. 81:2758-2765.

Melton, S. L. 1990. Effects of feeds on flavor of red meat: A review. J. Anim. Sci. 68:4421-4435.

Morrison, W. R., and L. M. Smith. 1964. Preparation of fatty acid methyl esters and dimethylacetals from lipids with boron fluoride-methanol. J. Lipid Res. 5:600-608.

Nguyen, L. Q., M. C. G. A. Nuijens, H. Everts, N. Salden, and A. C. Beynen. 2003. Mathematical relationships between the intake of n-6 and n-3 polyunsaturated fatty acids and their contents in adipose tissue of growing pigs. Meat Sci. 65:1399-1406.

NRC. 1998. Page 124-142 in Nutrient Requirements of Swine. 10th rev. ed. Natl. Acad. Press, Washington, DC.

Romans, J. R., R. C. Johnson, D. M. Wulf, G. W. Libal, and W. J. Costello. 1995. Effect of ground flaxseed in swine diets on pig performance and on physical and sensory characteristics and omega-3 fatty acid content in pork: II. Duration of $15 \%$ dietary flaxseed. J. Anim. Sci. 73:1987-1999.

Rosenvold, K., and H. J. Andersen. 2003. Factors of significance for pork quality: A review. Meat Sci. 64:219-237.

Rossell, J. B. 1994. Measurement of rancidity. Pages 22-53 in Rancidity in Foods. J. C. Allen and R. J. Hamilton, ed. Chapman and Hall, London. UK.

Sathivel, S., W. Prinyawiwatkul, J. M. King, C. C. Grimm, and S. Lloyd. 2003. Microwave-assisted catfish liver oil extraction and FA analysis. J. Am. Oil Chem. Soc. 80:15-20.

Sheard, P. R., M. Enser, J. D. Wood, G. R. Nute, B. P. Gill, and R. I. Richardson. 2000. Shelf life and quality of pork and pork products with raised n-3 PUFA. Meat Sci. 55:213-221.

Simopoulos, A. P. 2000. Human requirement for n-3 polyunsaturated fatty acids. Poult. Sci. 79:961-970.

Simopoulos, A. P. 2002. The importance of the ratio of omega-6/ omega-3 essential fatty acids. Biomed. Pharmacother. 56:365379.

Soler-Velasquez, M. P., J. H. Brendemuhl, L. R. McDowell, K. A. Sheppard, D. D. Johnson, and S. N. Williams. 1998. Effects of supplemental vitamin $\mathrm{E}$ and canola oil on tissue tocopherol and liver fatty acid profile of finishing swine. J. Anim. Sci. $76: 110-117$.

Spector, A. A. 1999. Essentiality of fatty acids. Lipids 34:S1-S3.

Viriyajari, P. 1992. Experiment and Analysis of Organoleptic Test. Department of Food Science and Technology, Chiang Mai University, Thailand.

Warnants, N., M. J. van Oeckel, and C. V. Boucqué. 1999. Incorporation of dietary polyunsaturated fatty acids into pork fatty acid tissues. J. Anim. Sci. 77:2478-2490.

Wenk, C., A. Häuser, D. Vogg-Perret, and A. L. Prabucki. 1990. Einfluss mehrfach ungesättigter Fettsäuren im Futter auf die Qualität von Schweinefleisch. Fat Sci. Technol. 92:552-556.

Wood, J. D., R. I. Richardson, G. R. Nute, A. V. Fisher, M. M. Campo, E. Kasapidou, P. R. Sheard, and M. Enser. 2003. Effects of fatty acids on meat quality: A review. Meat Sci. 66:21-32. 